This will engender confidence in obtaining predictable, anatomical contact areas resulting in improved patient-centred outcomes when restoring posterior interproximal cavities with direct composite.

\section{Ethics declaration}

The author declares no conflicts of interest.

\section{Acknowledgements}

The author wishes to acknowledge Christopher O'Connor for the use of his clinical images in Figure 12.

\section{References}

1. Khangura SD, Seal K, Esfandiari S et al. Composite resin versus amalgam for dental restorations: a health technology assessment. 2018. Available at https:// www.ncbi.nlm.nih.gov/books/NBK531946/ (accessed October 2021)

2. Rasines Alcaraz M G, Veitz-Keenan A, Sahrmann P, Schmidlin P R, Davis D, Iheozor-Ejiofor Z. Direct composite resin fillings versus amalgam fillings for permanent or adult posterior teeth. Cochrane Database Syst Rev 2014; D0I: 10.1002/14651858.CD005620.pub3.

3. Burke F J, Cheung S W, Mjor I A, Wilson N H. Restoration longevity and analysis of reasons for the placement and replacement of restorations provided by vocational dental practitioners and their trainers in the United Kingdom. Quintessence Int 1999; 30: 234-242.

4. Bailey O, Vernazza CR, Stone S, Ternent L, Roche A-G, Lynch C. Amalgam phase-down part 2: UK-based knowledge, opinions and confidence in the alternatives. JDR Clin Trans Res 2020; DOI: 10.1177/2380084420954766

5. Wilson $\mathrm{N} \mathrm{H}$, Lynch C D. The teaching of posterior resin composites: planning for the future based on 25 years of research. J Dent 2014; 42: 503-516.
6. Bailey O, Vernazza C R, Stone S, Ternent L, Roche A-G, Lynch C. Amalgam phase-down part 1: UK-based posterior restorative material and technique use. JDR Clin Trans Res 2020; DOI: 10.1177/2380084420978653.

7. Hellie C M, Charbeneau G T, Craig R G, Brandau HE. Quantitative evaluation of proximal tooth movement effected by wedging: a pilot study. J Prosthet Dent 1985; 53: 335-341.

8. Lynch C D, Farnell D J J, Stanton H, Chestnutt I G, Brunton P A, Wilson N H F. No more amalgams: use of amalgam and amalgam alternative materials in primary dental care. Br Dent J 2018; 225: 171-176.

9. Hancock E B, Mayo C V, Schwab R R, Wirthlin M R. Influence of interdental contacts on periodontal status. J Periodontol 1980; 51: 445-449.

10. Jernberg G R, Bakdash M B, Keenan K M. Relationship between proximal tooth open contacts and periodontal disease. J Periodontol 1983; 54: 529-533.

11. Peumans M, Van Meerbeek B, Asscherickx K et al. Do condensible composites help to achieve better proximal contacts? Dent Mater 2001; 17: 533-541.

12. El-Shamy H, Sonbul H, Alturkestani $\mathrm{N}$ et al. Proximal contact tightness of class bulk-fill composite resin restorations: an in vitro study. Dent Mater J 2019; 38: 96-100.

13. Wirsching E, Loomans B A, Klaiber B, Dörfer C E. Influence of matrix systems on proximal contact tightness of 2-and 3-surface posterior composite restorations in vivo. J Dent 2011; 39: 386-390.

14. Ahmad M Z, Gaikwad R N, Arjumand B. Comparison of two different matrix band systems in restoring two surface cavities in posterior teeth done by senior undergraduate students at Qassim University, Saudi Arabia: A randomized controlled clinical trial. Indian J Dent Res 2018; 29: 459-464.

15. Gomes I A, Filho E M, Mariz D C et al. In vivo Evaluation of proximal resin composite restorations performed using three different matrix systems. J Contemp Dent Pract 2015; 16: 643-647.

16. Loomans B A, Opdam N J, Roeters F J, Bronkhorst E M Huysmans M C. Restoration techniques and marginal overhang in class II composite resin restorations. J Dent 2009: 37: 712-717.

17. Saber M H, Loomans B A, El Zohairy A, Dorfer C E,
El-Badrawy W. Evaluation of proximal contact tightness of Class II resin composite restorations. Oper Dent 2010 35: 37-43.

18. Kampouropoulos D, Paximada C, Loukidis M, Kakaboura A. The influence of matrix type on the proximal contact in class II resin composite restorations. Oper Dent 2010 35: 454-462

19. Loomans B A, Roeters F J, Opdam N J, Kuijs R H. The effect of proximal contour on marginal ridge fracture of class II composite resin restorations. J Dent 2008; 36: 828-832.

20. Chow Y, Eber R, Tsao Y, Shotwell J, Wang H. Factors associated with the appearance of gingival papillae. J Clin Periodontol 2010; 37: 719-727.

21. Chuang SF, Su KC, Wang CH, Chang CH. Morphological analysis of proximal contacts in class II direct restorations with 3D image reconstruction. J Dent 2011; 39: 448-456.

22. Cazzaniga G, Ottobelli M, Ionescu A, Garcia-Godoy $F$, Brambilla E. Surface properties of resin-based composite materials and biofilm formation: a review of the current literature. Am J Dent 2015; 28: 311-320.

23. Millar B, Blake K. The influence of overhanging restoration margins on interproximal alveolar bone levels in general dental practice. Br Dent J 2019; 227: 223-227.

24. Pinna R, Usai P, Filigheddu E, Garcia-Godoy F, Milia E. The role of adhesive materials and oral biofilm in the failure of adhesive resin restorations. Am J Dent 2017 30: 285-292

25. Czerwinski M. Teflon floss on premolar. YouTube 2017. Available at https://www.youtube.com/ watch?v=w01L5UNRAdU (accessed January 2021).

26. Bailey $0,0^{\prime}$ Connor C. Papilla management in subgingival, interproximal, direct composite restoration: a key step to success. Br Dent J 2019; 226: 933-937.

27. Loomans B A, Opdam N J, Roeters F J, Huysmans M C Proximal marginal overhang of composite restorations in relation to placement technique of separation rings. Oper Dent 2012; 37: 21-27.

28. Loomans B A, Opdam N J, Roeters F J, Bronkhurst E $M$, Plasschaert A J. The long-term effect of composite restorations on proximal contact tightness. J Dent 2007; 35: 104-108.

This article is licensed under a Creative Commons Attribution 4.0 International License, which permits use, sharing, adaptation, distribution and reproduction in any medium or format, as long as you give appropriate credit to the original author(s) and the source, provide a link to the Creative Commons licence, and indicate if changes were made. The images or other third party material in this article are included in the article's Creative Commons licence, unless indicated otherwise in a credit line to the material. If material is not included in the article's Creative Commons licence and your intended use is not permitted by statutory regulation or exceeds the permitted use, you will need to obtain permission directly from the copyright holder. To view a copy of this licence, visit http://creativecommons.org/licenses/by/4.0. (c) The Author(s) 2021

\title{
Correction to: Honours, awards, appointments
}

The original article can be found online at https://doi.org/10.1038/s41415-021-3538-2.

\section{Journal's correction note:}

News article Br Dent J 2021; 231: 373.

When this article was originally published, the affiliation for Nabeel Ilyas was incorrectly listed as 'ST1 Paediatric Dentistry, King's College NHS

Trust' and should have read 'ST3 Paediatric Dentistry, King's College NHS Trust'.

The journal apologises for any inconvenience caused. 